\title{
Association of Frailty with Serum Vitamin D and Parathyroid Hormone Levels
}

\author{
Şemsinnur Göçer ${ }^{1}$ (D) , Özlem Balbaloğlu² (iD
}

${ }^{1}$ Bozok University, Sarıkaya Physical Therapy and Rehabilitation High School, Yozgat, Turkey

${ }^{2}$ Bozok University, Medicine School, Yozgat, Turkey

Şemsinnur GÖÇER

Özlem BALBALOĞLU
Correspondence: Şemsinnur Göçer Bozok University, Sarıkaya Physical Therapy and Rehabilitation High School, Yozgat, Turkey Phone: +905058394619

E-mail: semsinnurgocer@gmail.com

$\begin{array}{ll}\text { Received } & : \text { J June } 2021 \\ \text { Accepted } & : \text { 23 September } 2021\end{array}$

\section{ABSTRACT}

Objective: Studies investigating the effect of vitamin D and parathyroid hormone (PTH) in frailty syndrome are limited. Therefore, we aimed to evaluate the relationship between frailty and serum vitamin D and PTH levels.

Material and Methods: This is a cross-sectional study conducted on individuals aged $>65$ years. In this cross-sectional study, data were collected using sociodemographic data sheet, Fatigue, Resistance, Ambulation, Illnesses, \& Loss of Weight (FRAIL) scale and Study of Osteoporotic Fracture (SOF) index via face-to-face interview. The study included data from 513 subjects. Chi-square test was used in analyses. A p value $<0.05$ was considered as statistically significant.

Results: The mean age was $71.9 \pm 6.4$ years in the study population. The prevalence of frailty elder was found as $46.8 \%$ by FRAIL scale and $51.3 \%$ by SOF index while pre-fail elder prevalence was found as $45.2 \%$ by FRAIL scale and $33.3 \%$ by SOF index.

Conclusion: In our study it was found that frail elder prevalence was increased by advancing age, female gender and presence of comorbidity and that low serum vitamin D and elevated PTH levels were closely associated with prevalence of frail elder.

Keywords: Frailty, vitamin D, parathyroid hormone, elderly

\section{Kırılganlığın Serum D Vitamini Ve Paratiroid Hormon Düzeyleriyle İlişkisi}

ÖZET

Amaç: Kırılgan yaşlı sendromunun patobiyolojisi ile ilgili bilgiler kısıtlıdır. Kırılgan yaşlı sendromunun biyolojik yaşlanmaya bağlı oluşan hematolojik, immünolojik, endokrin ve metabolik sistemdeki değişiklikler ile birlikte çevresel faktörlerin sorumlu olabileceği düşünülmektedir. Bu araştırmanın amacı 65 yaş ve üzeri bireylerde kan bazlı biyobelirteçler ve kırılganlık arasındaki ilişkinin iki farklı kıııganlık indeksine göre değerlendirilmesidir.

Gereç ve Yöntemler: Bu çalışma 65 yaş ve üzeri bireylerde kan bazlı biyobelirteçler ve kırılganlık arasındaki ilişkinin belirlenmesi amacıyla yapıımış kesitsel bir çalışmadır. Veriler; sosyodemografik anket formu, FRAiL Kııılganlık Ölçeği ve Osteoporotik Kııık Çalışma İndeksi kullanılarak toplanmıştır. Veriler yüz yüze görüşme yöntemiyle toplanmış ve 513 kişiye ait veriler değerlendirilmiştir. Analizlerde Pearson's Ki kare testi kullanılmış olup, $p<0.05$ değeri anlamlı kabul edilmiştir.

Bulgular: Araştırma grubumuzun yaş ortalaması $71.9 \pm 6.4$ yıl idi. Kırılgan yaşlı prevalansı FRAiL İndekse göre \%46.8 iken SOF İndeksine göre \%51.3; pre-frail olanların prevalansı ise FRAiL İndeksine göre $\% 45.2$ iken SOF İndeksine göre $\% 33.3$ bulundu.

Sonuç: Çalışmamızda, kırılgan yaşı prevalansının, yaşın ilerlemesi, kadın cinsiyet ve komorbidite ile artış gösterdiği, ayrıca serumda düşük D vit düzeyi ile yüksek PTH düzeylerinin de KYS ile yakından ilişkili olduğu bulunmuştur.

Anahtar Sözcükler: Kırılganlık, D vitamini, paratiroid hormon, yaşlııı 
$\mathbf{T}$ here are various definitions of frailty syndrome, emphasizing altered mobility, weakness and nutritional impairment in the syndrome. However, the most widely definition used for fragile elderly syndrome; It is an increased sensitivity to external stresses due to age-related physiological reserves, loss of function in neuromuscular, metabolic and immune systems (1-3). In frail elder, the limited reserves can readily lead disabling damage even with minimal stress $(1,4,5)$. It is extremely important to distinguish between the normal aging process and the symptoms of CFS by following the physiological changes due to aging $(1,4,5)$. Thus, it is highly important to diagnose frailty syndrome in early phase and determine the stage in order to manage process in an appropriate manner $(6,7)$.

In the study found an association between low vitamin $D$ levels and risk of frailty syndrome in Italian male elderly (8). Additionally, in a study of older adults a similar result was determined (9). Again, in a recent study, a crosssectional relationship was found between low vitamin D levels and frailty in female American elders (10). In a study on integrated geriatric care from Taiwan, an association was determined between low vitamin D level and frailty in elder individuals (11). In most studies, serum 25-hydroxyvitamin $\mathrm{D}[25(\mathrm{OH}) \mathrm{D}]$ level was used as an indicator of vitamin D status (12).

Studies showing the effect of vitamin $d$ and parathyroid hormone on fraility are limited $(13,14)$. Therefore, the potential etiological link between vitamin D, PTH and frailty has not been identified.

The aim of this study is to define the effect of frailty and vitamin D and PTH on frailty in persons aged 65 and over.

\section{MATERIAL AND METHODS}

\section{Study design}

The study is a cross-sectional study on individuals aged $>65$ years.

\section{Study setting}

This study was conducted at Physical Therapy and Rehabilitation outpatient clinic of Bozok University, Medicine School between October, 2019 and February, 2020.

\section{Study population}

This study included individuals aged $>65$ years. In many studies using different definitions of frailty, frailty prevalence has been reported as $7.0-32.0 \%$ with higher rates among female individuals $(4,15,16)$. In studies from Turkey, frailty prevalence has been reported as $27.8-44.5 \%$ $(17,18)$. Based on these studies, minimum sample size was estimated to be 318 subjects using frailty prevalence of $30 \%$ in $95 \%$ confidence interval and alpha level of $5.0 \%$. The study included 513 subjects. Individuals under the age of 65 and using calcium and vitamin D were not included in the study.

\section{Tools and data collection}

Data were collected using sociodemographic data sheet, FRAIL scale (19) and Study of Osteoporotic Fracture (SOF) index (20).

\section{Sociodemographic data sheet}

Sociodemographic data sheet designed by researchers included 10 items questioning age, marital status, educational level, income level, occupation, systemic disorders and medications.

\section{Fatigue, Resistance, Ambulation, Illnesses, \& Loss of Weight (FRAIL) scale}

The FRAIL scale was developed by Morley et al. in 2012 (19). The scale included 5 items. The validation studies were conducted in many languages, proving its effectiveness in detection of frailty (21-25). The 5-item FRAIL scale assess fatigue, resistance, ambulation, diseases and loss of weight by 2 -points rating scale ( 0 or 1 ). In the scale, 0 point is accepted as non-frail while 1-2 points as pre-frail and $>2$ points as frail (19).

\section{Study of Osteoporotic Fracture (SOF) Index}

In the elderly individual, more than $5 \%$ weight loss (willingly or unwillingly in the last year), the inability to get up from the chair without using the arms five times and the "Do you feel energetic?" It is based on the assessment of their status of answering "no" to the question. Fraility is defined as no ( 0 component), pre-fragility ( 1 component) called medium and fragile ( $\geq 2$ component) $(20,26)$.

\section{Laboratory evaluation}

The laboratory data regarding calcium, phosphor, magnesium, PTH and vitamin D within prior 3 months were retrospectively extracted from hospital database. 
Serum phosphor, magnesium and calcium levels were classified as low, normal or high according respective reference ranges. Serum PTH level was classified as high if it was above upper limit of reference range while as normal if it was within reference range.

Serum $25(\mathrm{OH})$ D levels were measured by Architect i2000 (Abbott, Diagnostics, Wiesbaden, Germany) using chemiluminescent microparticle immunoassay technology. The linearity of the test was 3.4-155.9 ng / ml. The manufacturer reports an within-assay precision of $2.3 \%, 2.1 \%, 2.8 \%$ and a total precision of $3 \%, 3.1 \%$, and $4.1 \%$ for values of 20, 40, $78.3 \mathrm{ng} 7 \mathrm{dl}$ (respectively). Serum $25(\mathrm{OH}) \mathrm{D}$ levels $<10 \mathrm{ng} / \mathrm{ml}$ severe deficiency, 10-20 ng / $\mathrm{ml}$ deficiency, 21-29 ng / $\mathrm{ml}$ insufficiency and $30 \mathrm{ng} / \mathrm{ml}$ were considered sufficient. Measurements of serum $25(\mathrm{OH})$ D levels are considered the best indicator for assessing vitamin $D$ status (27).

\section{Ethics}

The study was approved by Ethics Committee on Clinical Research of Bozok University (2017_KAEK189_2019.10.16_06). The work followed the rules of Helsinki Declaration.

\section{Data analysis}

The statistics are presented as mean \pm standard deviation or frequency (\%). The correlation between selected variables and frailty was assessed using Pearson's chi-square analysis. In all analyzes, $\mathrm{p}<0.05$ values were considered significant.

\section{Limitations}

This study has some limitations including cross-sectional and single-center design. These may prevent to generalize our findings in different settings.

\section{RESULTS}

Mean age was $71.9 \pm 6.4$ years in the study population. Of the subjects, $75.2 \%$ were women and $77.2 \%$ were married while $61.8 \%$ were illiterate and $99.2 \%$ had own income.

It was found that there was at least one chronic disease in $83.6 \%$ of subjects while $83.6 \%$ was using at least one medication. Based on laboratory results, it was found that vitamin D level was low in $94.5 \%$ while PTH level was normal in $84.6 \%$ of subjects. In addition, it was found that calcium level was low in $3.7 \%$ of subjects. Regarding phosphor and magnesium levels, $97.3 \%$ and $97.0 \%$ of subjects had normal levels, respectively. Table 2 presents health-related parameters and laboratory results in the study population.

\begin{tabular}{|c|c|c|c|}
\hline Variables & Groups & Count & $\%$ \\
\hline \multirow{3}{*}{ Age groups } & $65-74$ years & 365 & 71.2 \\
\hline & $75-84$ years & 113 & 22.0 \\
\hline & & 35 & 6.8 \\
\hline Mean age (yrs) & \multicolumn{3}{|c|}{$71.9 \pm 6.4$} \\
\hline \multirow{2}{*}{ Gender } & Male & 127 & 24.8 \\
\hline & Female & 386 & 75.2 \\
\hline \multirow{4}{*}{$\begin{array}{l}\text { Educational } \\
\text { level }\end{array}$} & Illiterate & 317 & 61.8 \\
\hline & Literate & 31 & 6.0 \\
\hline & Primary school & 153 & 29.8 \\
\hline & >High school & 12 & 2.3 \\
\hline \multirow{2}{*}{ Marital status } & Married & 396 & 77.2 \\
\hline & Single & 117 & 22.8 \\
\hline \multirow{2}{*}{ Income } & Yes & 473 & 92.2 \\
\hline & No & 40 & 7.8 \\
\hline
\end{tabular}

Table 2: Health-related parameters and laboratory results in the study population (n: 513)

\begin{tabular}{|c|c|c|c|}
\hline \multirow{2}{*}{$\begin{array}{c}\text { Chronic } \\
\text { disease }\end{array}$} & Yes & Count & $\%$ \\
\cline { 2 - 4 } & No & 429 & 83.6 \\
\hline \multirow{3}{*}{ Medication } & Yes & 429 & 16.4 \\
\cline { 2 - 4 } & No & 84 & 83.6 \\
\hline \multirow{2}{*}{ Vitamin D } & Low & 485 & 16.4 \\
\cline { 2 - 4 } & Normal & 28 & 94.5 \\
\hline \multirow{3}{*}{ Calcium } & Normal & 494 & 5.5 \\
\cline { 2 - 4 } & Low & 19 & 96.3 \\
\hline \multirow{2}{*}{\begin{tabular}{c} 
Phosphor \\
\cline { 2 - 4 }
\end{tabular}} & Normal & 499 & 3.7 \\
\cline { 2 - 4 } Magnesium & Low & 14 & 97.3 \\
\cline { 2 - 4 } & Normal & 498 & 2.7 \\
\hline \multirow{3}{*}{$\begin{array}{c}\text { Parathyroid } \\
\text { hormone }\end{array}$} & Low & 15 & 97.0 \\
\cline { 2 - 4 } & Normal & 434 & 8.9 \\
\cline { 2 - 4 } & Low & 64 & 12.5 \\
\hline
\end{tabular}


In the study population, frailty prevalence was $46.8 \%$ by FRAIL scale whereas $51.3 \%$ by SOF index. According to the FRAIL scale, the prevalence of frailty was found to be $48.8 \%$ in subjects aged $65-74,49.6 \%$ in subjects aged 75 84 , and $82.9 \%$ in subjects aged 85 and over. The frequency of frailty in individuals aged 85 and over was higher and significantly higher than other age groups.

The prevalence of fragility according to the SOF index is $42.2 \%$ in people aged $65-74,68.1 \%$ between the ages of $75-84$ and $91.4 \%$ in persons aged $\geq 85$ years. The frequency of frailty was significantly higher in subjects aged 85 years and older than in other age groups.

In addition, $43.8 \%$ and $40.8 \%$ of subjects aged $65-74$ years were rated as pre-frail according to FRAIL scale and SOF index.

Frailty prevalence was determined to be significantly higher in females than males on both scales. (FRAIL scale; $53.4 \%, 26.8 \%$ and SOF index: $58.3 \%, 29.9 \%)$. The frailty prevalence was significantly higher in subjects with 5 or more chronic diseases by both scales (FRAIL scale: $83.3 \%$ and SOF index: $58.9 \%$ ) The frailty prevalence was 50.6\% by FRAIL scale and $56.9 \%$ by SOF index in subjects using at least one medication, indicating significantly higher prevalence.

In the evaluation made according to serum vitamin D levels, it was determined that the prevalence of frailty was significantly higher in patients with low serum vitamin $D$ levels in both scales (FRAIL scale: $46.1 \%$ and SOF index: $50.3 \%)$.

The frailty prevalence was $57.9 \%$ in subjects with low calcium levels but there was no significant difference according to FRAIL scale, while it was $52.2 \%$ in subjects with calcium level at lower limit of normal, indicating a significant difference according to SOF index.

According to FRAIL scale, of the subjects with high PTH level, $20 \%$ were pre-fail and $80 \%$ were frail. The frailty prevalence was significantly higher in these subjects. According to SOF index, $60.0 \%$ of subjects with high PTH level were pre-fail while $40 \%$ were frail, indicating significant difference in frailty prevalence.

Table 3 presents relationship of frailty with selected variables stratified according to frailty status.

\section{DISCUSSION}

In our study population, the frailty prevalence was found as $48.3 \%$ by FRAIL scale and $50.3 \%$ by SOF index while pre-frail prevalence as $45.2 \%$ by FRAIL scale and $33.3 \%$ by SOF index.

In the literature, it has been suggested that frailty prevalence varies from $7.0 \%$ to $32.0 \%$ in community-dwelling elder individuals $(27,28)$. In a study conducted in Turkey, which is $27.8 \%$ prevalence of frailty in the elderly has been reported (29). The term pre-frail defines elder individuals not meeting all of frailty criteria but at risk for frailty. The prevalence of pre-frail has been reported as $28-0-44.0 \%$ in the literature (30). In our study, both frail and pre-frail prevalence were found to be slightly higher than those reported in the literature.

In addition, in our study, it was determined that the prevalence of frailty was significantly higher by both scales in 85-year-old patients whose prevalence increased with age. Many studies have shown that the frequence of frailty increases with age (3). By advancing age, With advancing age, decreased slowness, physiological reserves, fatigue, decreased physical activity, fatigue and decreased body mass index become more common and are known to cause an increase in the prevalence of frailty decreased slowness, physiological reserves, fatigue, reduced physical activity, exhausting and decreased body mass index become more common, causing an increase in the frailty prevalence $(1,4)$.

Gender is another factor that affects the frailty syndrome. Being a woman is a risk factor for vulnerability. In the studies found that frailty was more in women. Similarly, in our study, it was sighted that the prevalence of fragility in females was higher than in male subjects in terms of both the FRAIL scale $(53.4 \%, 26.8 \%)$ and the SOF index (58.3\%,29.9\%). In addition, frail prevalence was also found to be higher in subjects with 5 or more diseases by both FRAIL score and SOF index. It has been thought that the difference in frailty prevalence between women and men could be related with higher strength and muscle mass in men. In our study, it was found that $83.6 \%$ of subjects had at least one chronic disease and was using at least one medication. The frail prevalence was significantly higher in subjects with 5 or more chronic disease (FRAIL scale: $83.3 \%$ and SOF index: $58.9 \%$ ). Moreover, it was also found to be significantly higher in subjects using at least one medication by both scales. It is well-known that presence of chronic disease is among factors related to frailty syndrome. In Brazilian study, it was found that 5 or more medication was associated to frailty syndrome and Zalavsky et al. also reported that chronic diseases was associated to risk for frailty syndrome (7). 
Table 3: The relationship of frailty with selected variables stratified according to frailty status (n: 513)

\begin{tabular}{|c|c|c|c|c|c|c|c|c|c|}
\hline & & \multicolumn{4}{|c|}{$\begin{array}{c}\text { FRAIL scale } \\
(\mathrm{n}: 513)\end{array}$} & \multicolumn{4}{|c|}{$\begin{array}{l}\text { SOF index } \\
\text { (n:513) }\end{array}$} \\
\hline \multirow{2}{*}{\multicolumn{2}{|c|}{ Parameters }} & Robust & Pre-frail & \multicolumn{2}{|c|}{ Frail } & Robust & Pre-frail & \multicolumn{2}{|c|}{ Frail } \\
\hline & & $\begin{array}{c}\mathrm{n}: 41 \\
(8.0 \%)\end{array}$ & $\begin{array}{c}n: 232 \\
(45.2 \%)\end{array}$ & \multicolumn{2}{|c|}{$\begin{array}{c}n: 240 \\
(46.8 \%) \\
\end{array}$} & $\begin{array}{c}n: 79 \\
(15.4 \%)\end{array}$ & $\begin{array}{c}\mathrm{n}: 171 \\
(33.3 \%)\end{array}$ & \multicolumn{2}{|c|}{$\begin{array}{c}n: 263 \\
(51.3 \%)\end{array}$} \\
\hline \multirow{3}{*}{ Age (yrs) } & $65-74$ & $\begin{array}{c}27 \\
(7.4 \%)\end{array}$ & $\begin{array}{c}160 \\
(43.8 \%)\end{array}$ & $\begin{array}{c}178 \\
(48.8 \%)\end{array}$ & \multirow{3}{*}{$\begin{array}{c}\text { Fisher's } \\
\text { exact test } \\
p<0.001\end{array}$} & $\begin{array}{c}62 \\
(17.0 \%)\end{array}$ & $\begin{array}{c}149 \\
(40.8 \%)\end{array}$ & $\begin{array}{c}154 \\
(42.2 \%)\end{array}$ & \multirow{3}{*}{$\begin{array}{c}\text { Fisher's } \\
\text { exact test } \\
p<0.001\end{array}$} \\
\hline & $75-84$ & $\begin{array}{c}14 \\
(12.4 \%)\end{array}$ & $\begin{array}{c}43 \\
(38.1 \%)\end{array}$ & $\begin{array}{c}56 \\
(49.6 \%)\end{array}$ & & $\begin{array}{c}16 \\
(14.2 \%)\end{array}$ & $\begin{array}{c}20 \\
(17.7 \%)\end{array}$ & $\begin{array}{c}77 \\
(68.1 \%)\end{array}$ & \\
\hline & $\geq 85^{*}$ & $\begin{array}{c}0 \\
(0.0 \%)\end{array}$ & $\begin{array}{c}29 \\
(82.9 \%)\end{array}$ & $\begin{array}{c}6 \\
(17.1 \%)\end{array}$ & & $\begin{array}{c}1 \\
(2.9 \%)\end{array}$ & $\begin{array}{c}2 \\
(5.7 \%)\end{array}$ & $\begin{array}{c}32 \\
(91.4 \%)\end{array}$ & \\
\hline \multirow{2}{*}{ Gender } & Male & $\begin{array}{c}33 \\
(26.0 \%)\end{array}$ & $\begin{array}{c}60 \\
(47.2 \%)\end{array}$ & $\begin{array}{c}34 \\
(26.8 \%)\end{array}$ & \multirow{2}{*}{$\begin{array}{c}\text { Fisher's } \\
\text { exact test } \\
p<0.001\end{array}$} & $\begin{array}{c}70 \\
(55.1 \%)\end{array}$ & $\begin{array}{c}19 \\
(15.0 \%)\end{array}$ & $\begin{array}{c}38 \\
(29.9 \%)\end{array}$ & \multirow{2}{*}{$\begin{array}{c}\text { Fisher's } \\
\text { exact test } \\
\mathrm{p}<0.001\end{array}$} \\
\hline & Female* & $\begin{array}{c}8 \\
(2.1 \%)\end{array}$ & $\begin{array}{c}172 \\
(44.6 \%)\end{array}$ & $\begin{array}{c}206 \\
(53.4 \%)\end{array}$ & & $\begin{array}{c}9 \\
(2.3 \%)\end{array}$ & $\begin{array}{c}152 \\
(39.4 \%)\end{array}$ & $\begin{array}{c}225 \\
(58.3 \%)\end{array}$ & \\
\hline \multirow{3}{*}{$\begin{array}{l}\text { Number } \\
\text { of Chronic } \\
\text { Diseases }\end{array}$} & None & $\begin{array}{c}25 \\
(29.8 \%)\end{array}$ & $\begin{array}{c}53 \\
(63.1 \%)\end{array}$ & $\begin{array}{c}6 \\
(7.1 \%)\end{array}$ & \multirow{3}{*}{$\begin{array}{c}\text { Fisher's } \\
\text { exact test } \\
p<0.001\end{array}$} & $\begin{array}{c}27 \\
(32.1 \%)\end{array}$ & $\begin{array}{c}35 \\
(41.7 \%)\end{array}$ & $\begin{array}{c}22 \\
(26.2)\end{array}$ & \multirow{3}{*}{$\begin{array}{c}X^{2}: 34.625 \\
p=0.001\end{array}$} \\
\hline & $<5$ & $\begin{array}{c}16 \\
(8.7 \%)\end{array}$ & $\begin{array}{c}138 \\
(75.4 \%)\end{array}$ & $\begin{array}{c}29 \\
(15.8 \%)\end{array}$ & & $\begin{array}{c}23 \\
(12.6 \%)\end{array}$ & $\begin{array}{c}64 \\
(35.0 \%)\end{array}$ & $\begin{array}{c}96 \\
(52.5 \%)\end{array}$ & \\
\hline & $\geq 5 *$ & $\begin{array}{c}0 \\
(0.0 \%)\end{array}$ & $\begin{array}{c}41 \\
(16.7 \%)\end{array}$ & $\begin{array}{c}205 \\
(83.3 \%) \\
\end{array}$ & & $\begin{array}{c}29 \\
(11.8 \%)\end{array}$ & $\begin{array}{c}72 \\
(29.3 \%)\end{array}$ & $\begin{array}{c}145 \\
(58.9 \%)\end{array}$ & \\
\hline \multirow{2}{*}{ Medication } & Yes* & $\begin{array}{c}20 \\
(4.7) \\
\end{array}$ & $\begin{array}{c}192 \\
(44.8)\end{array}$ & $\begin{array}{c}217 \\
(50.6) \\
\end{array}$ & \multirow{2}{*}{$\begin{array}{c}X^{2}: 44.566 \\
p=0.001\end{array}$} & $\begin{array}{c}50 \\
(11.7 \%) \\
\end{array}$ & $\begin{array}{c}135 \\
(31.5 \%) \\
\end{array}$ & $\begin{array}{c}244 \\
(56.9 \%) \\
\end{array}$ & \multirow{2}{*}{$\begin{array}{c}X^{2}: 42.669 \\
p=0.001\end{array}$} \\
\hline & No & $\begin{array}{c}21 \\
(25.0)\end{array}$ & $\begin{array}{c}40 \\
(\% 47.6)\end{array}$ & $\begin{array}{c}23 \\
(\% 27.4) \\
\end{array}$ & & $\begin{array}{c}29 \\
(34.5 \%)\end{array}$ & $\begin{array}{c}36 \\
(42.9 \%)\end{array}$ & $\begin{array}{c}19 \\
(22.6 \%)\end{array}$ & \\
\hline \multirow{2}{*}{ Vitamin D } & Low* & $\begin{array}{c}25 \\
(5.1 \%)\end{array}$ & $\begin{array}{c}226 \\
(46.6 \%) \\
\end{array}$ & $\begin{array}{c}234 \\
(48.3 \%) \\
\end{array}$ & \multirow{2}{*}{$\begin{array}{l}\text { Fisher's } \\
\text { exact test } \\
p=0.004\end{array}$} & $\begin{array}{c}73 \\
(15.1 \%) \\
\end{array}$ & $\begin{array}{c}168 \\
(34.6 \%)\end{array}$ & $\begin{array}{c}244 \\
(50.3 \%)\end{array}$ & \multirow{2}{*}{$\begin{array}{c}\text { Fisher's } \\
\text { exact test } \\
p=0.002\end{array}$} \\
\hline & Normal & $\begin{array}{c}16 \\
(57.2 \%) \\
\end{array}$ & $\begin{array}{c}6 \\
(21.4 \%) \\
\end{array}$ & $\begin{array}{c}6 \\
(21.4 \%) \\
\end{array}$ & & $\begin{array}{c}6 \\
(21.5 \%) \\
\end{array}$ & $\begin{array}{c}3 \\
(10.8 \%)\end{array}$ & $\begin{array}{c}19 \\
(67.7 \%)\end{array}$ & \\
\hline \multirow{2}{*}{ Calcium } & Normal & $\begin{array}{c}41 \\
(8.3 \%)\end{array}$ & $\begin{array}{c}224 \\
(45.3 \%)\end{array}$ & $\begin{array}{c}229 \\
(46.4 \%)\end{array}$ & \multirow{2}{*}{$\begin{array}{l}\text { Fisher's } \\
\text { exact test } \\
p=0.565\end{array}$} & $\begin{array}{c}73 \\
(14.8 \%)\end{array}$ & $\begin{array}{c}163 \\
(33.0 \%)\end{array}$ & $\begin{array}{c}258 \\
(52.2 \%)\end{array}$ & \multirow{2}{*}{$\begin{array}{c}\text { Fisher's } \\
\text { exact test } \\
p=0.034\end{array}$} \\
\hline & Low* & $\begin{array}{c}0 \\
(0.0 \%)\end{array}$ & $\begin{array}{c}8 \\
(42.1 \%)\end{array}$ & $\begin{array}{c}11 \\
(57.9 \%)\end{array}$ & & $\begin{array}{c}6 \\
(31.6 \%) \\
\end{array}$ & $\begin{array}{c}8 \\
(42.1 \%) \\
\end{array}$ & $\begin{array}{c}5 \\
(26.3 \%) \\
\end{array}$ & \\
\hline \multirow{3}{*}{$\begin{array}{c}\text { Parathyroid } \\
\text { hormone }\end{array}$} & Normal & $\begin{array}{c}40 \\
(9.2 \%)\end{array}$ & $\begin{array}{c}174 \\
(40.1 \%)\end{array}$ & $\begin{array}{c}220 \\
(50.7 \%)\end{array}$ & \multirow{3}{*}{$\begin{array}{c}\text { Fisher's } \\
\text { exact test } \\
p<0.001\end{array}$} & $\begin{array}{c}74 \\
(17.1 \%)\end{array}$ & $\begin{array}{c}128 \\
(29.5 \%)\end{array}$ & $\begin{array}{c}232 \\
(53.5 \%)\end{array}$ & \multirow{3}{*}{$\begin{array}{c}\text { Fisher's } \\
\text { exact test } \\
p<0.001\end{array}$} \\
\hline & Low & $\begin{array}{c}1 \\
(1.6)\end{array}$ & $\begin{array}{c}55 \\
(85.9)\end{array}$ & $\begin{array}{c}8 \\
(12.5)\end{array}$ & & $\begin{array}{c}5 \\
(7.8 \%)\end{array}$ & $\begin{array}{c}34 \\
(53.1 \%)\end{array}$ & $\begin{array}{c}25 \\
(39.1 \%)\end{array}$ & \\
\hline & High* & $\begin{array}{c}0 \\
(0.0 \%)\end{array}$ & $\begin{array}{c}3 \\
(20.0 \%)\end{array}$ & $\begin{array}{c}12 \\
(80.0 \%)\end{array}$ & & $\begin{array}{c}0 \\
(0.0 \%)\end{array}$ & $\begin{array}{c}9 \\
(60.0 \%)\end{array}$ & $\begin{array}{c}6 \\
(40.0 \%)\end{array}$ & \\
\hline
\end{tabular}

The relationship between serum $25(\mathrm{OH})$ vitamin $\mathrm{D}$ level and frailty is complex; Frailty is thought to be both the cause and the consequence of vitamin $D$ deficiency. However, vitamin D, which binds to vitamin D receptors (VDR), can increase de novo synthesis and cellular calcium uptake of the protein in the muscle cell, thus affecting muscle mass and physical performance, in addition, vitamin $25(\mathrm{OH}) \mathrm{D}, \mathrm{IL}-2$ and IL It can reduce inflammatory mediators such as -12 , thus it has been reported to affect physical performance and muscle strength (31).
It is stated that vitamin D deficiency is associated with poor physical performance in elderly individuals. Again, in a meta-analysis of 7 studies evaluating the relationship between vitamin $D$ and frailty, low vitamin $D$ levels were found to increase the risk of frailty. In the National Health and Nutrition Examination Survey III, it was determined that $25(\mathrm{OH}) \mathrm{D}<15 \mathrm{ng} / \mathrm{mL}$ increased the risk of frailty by 3.7 times (9). In our study, it was found that frailty prevalence by both FRAIL scale and SOF index was significantly higher in subjects with low serum vitamin $D$ level in agreement with literature. 
It is thought that there is vitamin D deficiency in $90 \%$ of elder individuals. It is most commonly due to dietary habits and insufficient exposure to sunlight. In elder individuals, gastrointestinal calcium absorption is decreased due to malnutrition and vitamin $D$ deficiency while renal calcium excretion is increased. The decreased dietary calcium intake can also contribute to reduced absorption and low blood calcium levels. Given these associations, it is also suggested that low calcium level caused by low $25(\mathrm{OH})$ D level can be associated to fall, fracture, sarcopenia, poor physical function, disability and frailty (32).

In our study, although frailty prevalence (57.9\%) was higher in subjects with low calcium level according to FRAIL scale, there was no significant difference. However, frailty prevalence was $52.2 \%$ in subjects with calcium level at lower limit of normal, indicating statistical significance.

A correlation was shown between elevated PTH levels and frailty in elder individuals. It is suggested that PTH can cause frailty through vitamin $D$ deficiency and increased intracellular calcium uptake (33). In our study, of the subjects with elevated PTH levels, $20.0 \%$ were pre-frail and $80 \%$ were frail; in addition, frailty prevalence was significantly higher according to FRAIL scale. Moreover, $60 \%$ of subjects with high PTH levels were pre-frail and $40 \%$ were frail according to SOF index. Our results are in agreement with literature.

The relationship between frailty and low $25(\mathrm{OH}) \mathrm{D}$ level may be related to active vitamin $D$ metabolites that downregulate inflammatory markers such as interleukin-2 and interleukin-12 (8).

Thus, the effects of low $25(\mathrm{OH}) \mathrm{D}$ on muscles may be mediated by proinflammatory cytokines known to affect physical performance and muscle strength (34) and in addition, low vitamin $D$ levels may indirectly influence the thought of secondary hyperparathyroidism.

In patients with hyperparathyroidism, muscle functions decrease and can be corrected by parathyroidectomy (35). Additionally, high PTH levels have also been associated with decreased physical activity $(8,13)$. It is also unclear whether the effects on muscle function are due to hypovitaminosis $D$ secondary to hyperparathyroidism or direct effects of PTH, such as increased intracellular calcium concentrations (36-40). Therefore, vitamin D deficiency may contribute to some of the negative consequences regarding frailty; however, further work is required to confirm or rule out this result.

Our understanding about pathobiology o frailty syndrome is limited. It is thought that changes in hematologic, immunological, endocrine and metabolic system caused by biological aging together with environmental factors can be involved in frailty syndrome. The frailty syndrome is not only reduction of strength in performing daily living activities but also severe condition that may result in hospitalization and death.

\section{CONCLUSION}

In conclusion, it was found that frailty prevalence is increased by advancing age, female gender and comorbid diseases and that low vitamin D level and elevated PTH levels are closely related to frailty syndrome. It is apparent that early diagnosis of frailty and exercises enhancing muscle strength, nutritional support and prevention of polypharmacy can prevent undesired outcomes such as morbidity and mortality.

\section{References}

1. Rockwood K, Song X, MacKnight C et al. A global clinical measure of fitness and frailty in elderly people. CMAJ 2005; 173: 489-95.

2. Topinkova E. Aging, disability and frailty. Ann Nutr Metab 2008; 52(Suppl 1): 6-11.

3. Walston J, Hadley EC, Ferrucci L, et al. Research agenda for frailty in older adults. toward a better understanding of physiology and etiology: Summary from the American Geriatrics Society/ National Institute on Ageing Research Conference on Frailty in Older Adults. J Am Geriat Soc 2006; 54(6):991-1001.

4. Fried LP, Ferrucci L, Darer J, Williamson JD, Anderson G. Untangling the concepts of disability, frailty, and comorbidity: implications for improved targeting and care. J Gerontol A Biol Sci Med Sci 2004;59(3):255-63.

5. Rose M, Pan H, Levinson MR, Staples M. Can frailty predict complicated care needs and length of stay? Intern Med J 2014; 44(8),800-5

6. Byard RW. Frailty syndrome-medicolegal considerations. Journal of forensic and legal medicine. 2015;30:34-8.

7. Zaslavsky O, Cochrane BB, Thompson HJ, Woods NF, Herting JR, LaCroix AA. Frailty: A Review Of The First Decade Of Research. Biological Research For Nursing 2012; 15(4):422-432.

8. Shardell M, Hicks GE, Miller RR et al. Association of low vitamin D levels with the frailty syndrome in men and women. J Gerontol A Biol Sci Med Sci 2009; 64: 69-75.

9. Wilhelm-Leen ER, Hall YN, Deboer IH, Chertow GM. Vitamin D deficiency and frailty in older Americans. J Intern Med 2010; 268: $171-80$.

10. Ensrud KE, Ewing SK, Fredman L et al. Circulating 25-hydroxyvitamin $D$ levels and frailty status in older women. J Clin Endocrinol Metab 2010; 95: 5266-73.

11. Chang $\mathrm{Cl}$, Chan DC, Kuo KN, Hsiung CA, Chen CY. Vitamin D insufficiency and frailty syndrome in older adults living in a Northern Taiwan community. Arch Gerontol Geriatr 2010; 50(Suppl 1): S17-21. 
12. Lips P. Vitamin D deficiency and secondary hyperparathyroidism in the elderly: consequences for bone loss and fractures and therapeutic implications. Endocr Rev 2001; 22:477-501.

13. Visser $M$, Deeg DJ, Lips $P$. Low vitamin $D$ and high parathyroid hormone levels as determinants of loss of muscle strength and muscle mass (sarcopenia): the Longitudinal Aging Study Amsterdam. J Clin Endocrinol Metab 2003; 88: 5766-72.

14. Houston DK, Cesari M, Ferrucci L et al. Association between vitamin D status and physical performance: the InCHIANTI study. J Gerontol A Biol Sci Med Sci 2007; 62: 440-6.

15. Fried $L P$, Tangen $C M$, Walston J.et al Frailty in older adults: evidence for a phenotype. J Gerontol A Biol Sci Med Sci 200156M146-M157. [PubMed] [Google Scholar]

16. Mitnitski A, Song X, Skoog l.et al Relative fitness and frailty of elderly men and women in developed countries and their relationship with mortality. J Am Geriatr Soc 2005531069-1070. [PubMed] [Google Scholar]

17. Akın S, Mazıcıoglu MM, Mucuk S, Gocer S, Deniz Şafak E, Arguvanlı $S$, et al. The prevalence of frailty and related factors in communitydwelling Turkish elderly according to modified Fried Frailty Index and FRAIL scales. Aging Clin Exp Res 2015; 27(5): 703-9.

18. Eyigor S, Kutsal YG, Duran E, Huner B, Paker N, Durmus B, et al. Frailty prevalence and related factors in the older adult_FrailTURK Project. Age (Omaha) 2015; 37(3): 50.

19. Morley JE, Malmstrom TK, Miller DK (2012) A simple frailty questionnaire (FRAIL) predicts outcomes in middle aged African Americans. J Nutr Health Aging 16(7):601-608.

20. Ensrud KE, Ewing SK, Taylor BC, et al. Comparison of 2 frailty indexes for prediction of falls, disability, fractures, and death in older women. Arch Intern Med 2008; 168(4):382-9.

21. Jung HW, Yoo HJ, Park SY, Kim SW, Choi JY, Yoon SJ, et al. The Korean version of the FRAIL scale: clinical feasibility and validity of assessing the frailty status of Korean elderly. Korean J Intern Med. 2016;31(3):594-600.

22. Diaz de Leon Gonzalez E, Gutierrez Hermosillo H, Martinez Beltran JA, Chavez JH, Palacios Corona R, Salinas Garza DP, et al. Validation of the FRAIL scale in Mexican elderly: results from the Mexican Health and Aging Study. Aging Clin Exp Res. 2016;28(5):901-8.

23. Dong L, Qiao X, Tian X, Liu N, Jin Y, Si H, et al. Cross-Cultural Adaptation and Validation of the FRAIL Scale in Chinese Community-Dwelling Older Adults. J Am Med Dir Assoc. 2017. 60

24. Gardiner PA, Mishra GD, Dobson AJ. Validity and responsiveness of the FRAIL scale in a longitudinal cohort study of older Australian women. J Am Med Dir Assoc. 2015;16(9):781-3.

25. Lopez D, Flicker L, Dobson A. Validation of the frail scale in a cohort of older Australian women. J Am Geriatr Soc. 2012;60(1):171-3.

26. Yesavage $J A$, Brink $T L$, Rose $T L$, Lum $O$, Huang $V$, Adey $M$ et al (1982-1983) Development and validation of a geriatric depression screening scale: a preliminary report. J Psychiatr Res 17:37-49.

27. Holick MF, Binkley NC, Bischoff-Ferrari HA, Gordon CM, Hanley DA, Heaney RP et al. Evaluation, treatment, and prevention of vitamin $D$ deficiency: an Endocrine Society clinical practice guideline. J Clin Endocrinol Metab. 2011 Jul;96(7):1911-30.

28. Lally F, Crome P. Understanding frailty. Postgrad Med J 2007; ;83(975);16-20.

29. Akın S, Mazıcıoglu MM, Mucuk S, Gocer S, Deniz Şafak E, Arguvanlı $\mathrm{S}$, et al. The prevalence of frailty and related factors in communitydwelling Turkish elderly according to modified Fried Frailty Index and FRAIL scales. Aging Clin Exp Res 2015; 27(5): 703-9. Strandberg T. E, Pitkala K. H, Tilvis R.S. Frailty in older people. European Geriatric Medicine, 2011; 2(6): 344-355.
30. Woods NF, LaCroix AZ, Gray SL, Aragaki A, Cochrane BB, Brunner RL, et al. Frailty: emergence and consequences in women aged 65 and older in the Women's Health Initiative Observational Study. J Am Geriatr Soc. 2005;53(8):1321- 30.

31. Bandeen-Roche K, Xue QL, Ferrucci L, Walston J, Guralnik JM, Chaves, $P$, Zeger SL, Fried LP Phenotype of frailty: characterization in the women's health and aging studies. Journal of Gerontology: Medical Sciences 2006;61( 3); 262-266.

32. Pegoran MS, Tavares DMS. Factors associated with the frailty syndrome in elderly individuals living in the urban area. Rev Lat Am Enfermagem 2014; 22(5):874-882.

33. Zhou J, Huang P, Liu P, Hao Q, Chen S, Dong B, et al. Association of vitamin $D$ deficiency and frailty: A systematic review and metaanalysis. Maturitas 2016; 94: 70-6.

34. Artaza-Artabe I, Sáez-López P, Sánchez-Hernández N, FernándezGutierrez N, Malafarina V. The relationship between nutrition and frailty: Effects of protein intake, nutritional supplementation, vitamin $D$ and exercise on muscle metabolism in the elderly. A systematic review. Maturitas 2016; 93: 89-99.

35. Eyigor S., Kutsal Y. G. (2010). Kırılgan Yaslıya Yaklasım, Türk Fiz Tıp Rehab Dergisi, 56:135-40.

36. Chowdhury R, Peel NM, Krosch M, Hubbard RE. Frailty and chronic kidney disease: A systematic review. Arch Gerontol Geriatr 2017;68:135-42.

37. Tajar A, Lee DM, Pye SR, O'Connell MD, Ravindrarajah R, Gielen E, et al. The association of frailty with serum 25-hydroxyvitamin $D$ and parathyroid hormone levels in older European men. Age Ageing 2013;42(3):352-9.

38. Lips P. Vitamin D physiology. Prog Biophys Mol Biol 2006; 92: 4-8.

39. Cesari M, Penninx BW, Pahor $M$ et al. Inflammatory markers and physical performance in older persons: the InCHIANTI study. J Gerontol A Biol Sci Med Sci 2004; 59: 242-8.

40. Deutch SR, Jensen MB, Christiansen PM, Hessov I. Muscular performance and fatigue in primary hyperparathyroidism. World $J$ Surg 2000; 24: 102-7. 